\title{
Looking Flash: Disreputable Women’s Dress and 'Modernity', 1870-1910
}

\section{by Melissa Bellanta and Alana Piper}

\author{
Australian Catholic University, Sydney \\ Griffith University, Brisbane
}

melissa.bellanta@acu.edu.au
a.piper@griffith.edu.au

From Brazil to St Petersburg, Berlin to Melbourne, disreputable women in showy dress attracted abundant commentary in the late nineteenth and early twentieth centuries. In Australia, our focus here, as in other parts of the English-speaking world, the word ‘flash’ was often used for these women. 'Flash’ was a cant term originating in eighteenth-century England, used to indicate sexual and criminal knowledge as well as an interest in audaciously street-smart clothes. Gaudily attired prostitutes were sometimes called 'flash girls'; delinquent factory girls were said to have gone bad due to 'flash dress and fast companions'. ${ }^{1}$ Despite frequent use of the term, commentators rarely offer detailed descriptions of flash women's clothes. Most were content with vague references to 'scarlet satin' or 'tinsel imitations of rich adornments'. ${ }^{2}$ With this in mind, we here offer detailed examples of flash feminine street style between 1870 and 1910. The flash style was exhibited by certain prostitutes, brothel madams, thieves, barmaids, ballet girls, brazen factory-workers and unruly servants, especially those with a history of institutionalization under 'industrial schools' laws.

Though they drew attention from their contemporaries, disreputable women in flash dress have attracted little from historians. The only sustained discussions of street style between 1870 and 1910 focus on men. ${ }^{3}$ Historians of prostitution tend to refer only briefly to sex workers' sartorial style, often simply repeating the generic references to prostitutes' penchant for 'finery' to be found in contemporary commentaries. ${ }^{4}$ Feminist scholars interested in turn-of-the-century dress mostly concentrate on middle-class women. ${ }^{5}$ Problematically, too, the small number who investigate the dress practices of working-class women have tended to do so as part of a search for advance evidence of the 1920s 'Modern Girl'. Keen to present working-class women as pioneers of the modern femininity apparent in the Jazz Age, they have concentrated on shopgirls or 
aspirational garment workers who acted like proto-flappers, dressing for glamour and romance. ${ }^{6}$ Often sporting tattoos, sometimes even missing teeth, rougher women of the lower orders have made little of a showing in these scholars' works. This is presumably because they cannot be viewed so readily as putative 'Modern Girls'.

Turn-of-the-century streetwalkers and thievish servant girls in gaudy dress could as easily be said to look back to the 1700s, when the term 'flash' came into being, as forward to the 1920s. They were not, of course, untouched by changes wrought by mechanization and the expansion of consumer culture in their day. Some worked at the forefront of industrialization in Australia: in the boot-making factories of Collingwood in Melbourne or clothing workshops in Sydney’s Surry Hills, for example, which were just beginning to adopt techniques of mass production in the early 1900s. ${ }^{7}$ Others went on shopping sprees and frequented commercial entertainment venues when they had the chance. Even so, these women still maintained links with older gender and consumption practices. Rather than sweeping those older practices aside in favour of a 'modern' way of life, they subtly adapted them to accommodate contemporary developments.

In this article, we discuss flash feminine street style as it appeared in the capitals of the eastern Australian colonies between 1870 and 1910. We draw heavily on police gazettes, prison records and court depositions, in order to contribute new perspectives on the relationship between turn-of-the-century femininity, dress, fashion, and consumption. Offering details of low women's street style that are hard to find in other accounts, we show that eclecticism was the hallmark of flash feminine street dress. Flash ensembles were frequently hotchpotches of disparate items: second-hand and fashionable, stolen and purchased, plush and drab, ready-made and hand-sewn. They were a composite of newer and older dress practices, and thus resist being categorized either as 'traditional' or as 'modern' in style.

Though our examples come from Australia, this discussion has broader relevance. In the first place, the looks affected by flash Australian women were likely to be found among disreputable streetwise women in other localities. Given the traffic of people and commodities between Australia, other parts of the British Empire and the United States, this would have been the case across much of the English-speaking world. It is also likely to hold true for some non-Anglo and even non-Western locales. In the second place, we offer a more generalized critique of the preoccupation with 'modernity' 
among scholars of gender and consumption between 1870 and 1910. Our examples show that many such scholars underplay the durability of older gender and consumption practices and overplay the impact of so-called modernizing developments such as massmanufacturing on everyday life.

\section{A DEFINITION OF 'FLASH'}

In 1878, the evidence given by a Melbourne policeman to a parliamentary committee made it clear that 'flash' was a term commonly applied to gaudily dressed women of questionable morals. Asked for his views on why some women became prostitutes, Sergeant James Dalton pointed to a love of dress among women who could not afford fine clothes. These women decided to become prostitutes, because of the bad example set by 'flash girls', he said:

Even respectable girls notice them, though they do not like to be seen looking at them, still they are peeping side-long, and one will say to another - 'I am as goodlooking a girl as that, and I may be a drudge in the kitchen, and that girl is flaunting about in silks and satins'. Flash girls are the ruin of many girls. ${ }^{8}$

By the time Dalton used it, the term 'flash' was at least a century old. It had originated among criminal types in eighteenth-century London and been transported to Australia along with shiploads of British convicts from 1788. According to James Hardy Vaux, a convicted London thief sent to Australia in 1800, 'flash' had multiple meanings. It was firstly a generic term for the cant vocabulary - the so-called 'flash language' - used by thieves wanting to avoid being understood by law-abiding folk. It was secondly a verb meaning 'to display', in which sense it is still used today. Lastly, it was an adjective meaning 'cunning' or 'not easily duped', both synonyms for 'streetwise'. ${ }^{9}$ As a result of these various meanings, 'flash' was often used to refer to men or women who combined an interest in streetwise and criminal knowledges with a desire to distance themselves from 'straight' society through a love of show and bodily display.

In the case of women, the term 'flash' referred more specifically to sexual knowingness and display. Since the term was thus closely associated with prostitutes, the key sites for the enactment of flash style were the venues where these 'flash girls' 
were likely to solicit custom. The flash milieu accordingly comprised penny gaffs, theatres, gambling dens, horse races and bare-knuckle prize fights, as well as brothels and seamy pubs known as ‘flash kens'. ${ }^{10}$ When applied to dress, ‘flash' also effectively translated as 'audaciously street-smart' or 'flamboyantly streetwise'. ${ }^{11}$ The desire for flamboyant clothes was not of course confined to prostitutes and criminals. A great many common people longed to dress in a showier way. ${ }^{12}$ Nonetheless, a flash look could be distinguished from other kinds of 'showy' dress by how and where it was worn. In the eighteenth century, flash dressers made themselves known by the brazen manner with which they wore their clothes and by the equally 'flash' (that is, dodgy) places in which they wore them, if not also by the detail of the clothes themselves.

There are plenty of indications that a flash milieu developed in Australia over the first half of the nineteenth century. In the 1830s, a group of convict women at the Female Factory in Hobart called themselves the 'flash mob'. They set themselves apart from the other convicts by wearing earrings and coloured handkerchiefs acquired via a mix of standover tactics and sexual favours. Another group of convicts - in this case all men - were also calling themselves the 'flash mob' in the 1840s. Sent with the explorer Thomas Livingstone on an expedition into the Australian interior, they spent their time talking about prize-fights and singing cant-laden songs. In the same period the police superintendent William Augustus Miles used 'flash’ to refer to a scene frequented by thieves, prostitutes and other ne'er-do-wells around The Rocks in Sydney. ${ }^{13}$

While members of the 'lower sort' were living out flash culture in the 1830s and 1840s, the concept of 'flash' was also communicated to a more diffuse audience in those decades. This process began in England in the 1820s through the publication of texts such as Pierce Egan's Life in London (1821) and William Moncrieff's Tom and Jerry, or Life in London (1828). It continued over the following decades via such ‘Newgate novels’ as Edward Bulwer Lytton’s Jack Clifford (1830), William Harrison Ainsworth's Rookwood (1834) and Jack Sheppard (1839), Charles Whitehead's Autobiography of Jack Ketch (1834) and Charles Dickens's Oliver Twist (1838). Distributed throughout the English-speaking world and supplemented by theatrical versions and music-hall songs, these texts ensured that flash characters had gained a broad currency in popular culture by the late 1800s. ${ }^{14}$ 
The commodification of flash style took place on an even larger scale in the course of the twentieth century. Although its connotations of criminality had largely vanished by then, the term 'flash' could be found almost at every turn in later twentieth-century popular culture. It appeared in the title of the Rolling Stones hit 'Jumping Jack Flash' in 1968; in the name chosen by the rap-cum-hip hop pioneer Grandmaster Flash in the 1970s; and in the 1983 film Flashdance. The adjective 'flashy', meaning 'attentionseeking', also came into wider use. It is now applied to anything from sports cars to ostentatious designer clothes. The term 'flash mob’ has also acquired a new meaning in recent years. It currently refers to disparate groups who gather in public places, often in response to a call via social media, to give a one-off performance of some kind or perhaps a protest.

Though the concept of 'flash' was to change over time, there were still plenty of examples of the term being used at the dawn of the twentieth century in the same way as it had been in earlier decades. It still referred to a mode of appearance, way of life and a moral or social type linked to the sex trade and crime, in other words. In 1891, a man calling himself Flash Harry was wanted for assault in the inner-Sydney district of Glebe. Described by police as a 'spieler' in an overcoat with velvet collar and tweed suit, he was probably employed to talk up sales for stall-holders at markets or to drum up ticket sales outside theatre doors. ${ }^{15}$ Ten years later, New South Wales police sought the arrest of the 'very flash' hawker, Abdul Razzak. This man of 'very dark complexion' was suspected of theft and said to wear a 'flash silver watch chain'. In the same year, 1901, Queensland police put out a warrant for a barmaid wanted for the theft of a diamond and sapphire ring. Wearing her hat 'very low in front', she was said to be 'very flash'. 16

Not all disreputable women were flash, of course. Women suspected of crime appeared in any number of police gazette descriptions wearing plain dresses in dark colours and drab fabrics. ${ }^{17}$ Conversely, it took more than an interest in eye-catching dress to be flash. Photographic collections indicate that plenty of respectable women were dressing in bright fabrics with abundant trimmings after the 1870s. ${ }^{18}$ These women disobeyed the etiquette manuals of the day, which insisted on 'quiet' and 'harmonious' dress as a mark of feminine refinement. ${ }^{19}$ It is unlikely, however, that anyone wellversed in street culture would have called these women 'flash'. As in the eighteenth 
century, to qualify for that term one had to carry oneself with an air of sexual knowing, frequent 'low' venues and hail from apparently ‘rough’ origins.

\section{AN ECLECTIC LOOK}

In 1907, the Brisbane brothel madam Margaret Gregson made a sensational appearance in the local police court. Brought before the magistrate for assaulting one of her female 'boarders', she swept into the courtroom wearing 'six great rings, studded with diamonds and precious stones' on her right hand, more rings on her left hand, and gold chains, brooches and necklaces 'nestling in the rolls of her costly white lace bolero and fine white gown'. ${ }^{20}$ The notorious Madam Brussels caused a similar sensation when she arrived at a Melbourne court in 1906. Though she herself was 'quietly dressed', she entered the room with a 'train of dissolute ladies', each attired in 'resplendent millinery' and dresses swathed with lace and embroidery. ${ }^{21}$

While high-class brothel madams received plenty of publicity in the press, there were only a miniscule number of women involved in the Australian sex trade who could match their extravagance. Australia had very few grand brothels outside Melbourne. ${ }^{22}$ The absence of a royal court or aristocracy also meant that Australian society lacked a genuine equivalent to the European courtesan or Parisian demi-mondaine. Given this, the vast majority of flash women in Australia had little income to spend on dress. Indeed, even Madame Brussels’ 'girls’ were unlikely to have owned the ostentatious dresses they wore that day in the Melbourne police court. Evidence suggests that the managers of expensive brothels employed their own seamstresses, and that they retained ownership of the clothes. ${ }^{23}$

Most flash women could not afford to commission a whole outfit from a dressmakers, nor purchase one ready-made. In the absence of disposable income, they had to assemble a flash look through a range of ingenious and low-cost strategies. These included saving to buy special items new, possibly on an instalment plan, and shopping at pawnshops and second-hand stalls at places such as Melbourne's Eastern Market in Bourke Street, Sydney’s Paddy Market and its George St market. ${ }^{24}$ They also included begging for hand-me-downs from friends and family, and borrowing or stealing coveted items. ${ }^{25}$ The police gazettes are rife with descriptions of servants or prostitutes suspected of stealing clothing. Twenty-eight year old Annie Ewell, a woman missing 
her front teeth, offers an example of these. After allegedly stealing a black dress from her mistress in Carlton, Melbourne, she was later seen wearing a black dress and gem hat. ${ }^{26}$ It is also likely that flash women made and altered clothes for their own use. ${ }^{27}$

The fact that flash women had to engage in a mix of strategies in order to dress themselves ensured that eclecticism was the hallmark of their style. One gets a sense of this from a report on a Salvation Army meeting for 'fallen' women written by a Brisbane journalist in 1887. Those in attendance were 'dressed in all manner of ways', he wrote:

from elephant's-breath costumes of the latest cut, to tawdry, ill-fitting gowns of the cheapest and most glaring stuff; one in a yellow patterned smoking cap; many in a maze of ill-matched skirts, jackets, capes, hats, and jewellery, picked up haphazard; in furs and cottons; all with rings and most with short hair. ${ }^{28}$

Though the journalist considered the women's clothes to be the result of carelessness or a lack of aesthetic sensibility, their combination of unexpected items - a fur with a plain skirt, or a yellow-patterned smoking cap with a fashionable dress in 'elephant's breath' (a greyish shade of lavender then in vogue) - was actually part of a distinct aesthetic. ${ }^{29}$ To put this another way: flash women made eclecticism into an aesthetic virtue out of necessity. They took pride in the creativity required to repurpose old items, and in combining them with other items to produce a unique and distinctive look. In this, they had similarities to many marginalized and/or poor people striving to 'put on style': whether runaway slaves in eighteenth-century America, or the shoppers at second-hand markets in Zambia today. ${ }^{30}$

One can see the combination of unexpected items in the dress of Annie Lesberg, a woman who ran away from a Salvation Army Home in Melbourne in 1887. She wore a 'shabby blue short dress' teamed with a 'feather boa around her neck'. ${ }^{31}$ An unnamed adolescent girl admitted to Melbourne's Oakleigh reformatory in 1887 wore a 'dirty and lagged' gown in plain grey material 'liberally trimmed with red plush', topped by a black velvet hat embellished with a scarlet bird. ${ }^{32}$ Mug shots from Victoria's central register of female prisoners show a similar propensity for fancy trimmings on drab clothing: intricate lace collars, ornamental buttons and fur collars or cuffs. ${ }^{33}$ 
Another way that flash women exhibited an eclectic aesthetic was by combining multiple strong colours or prints in their clothes. An 1877 caricature entitled 'Led Astray!' portrayed a number of 'flash girls' and female performers in cheap variety halls (Fig. 1). The flash women in the street wore dresses of contrasting patterns and prints, conspicuous jewellery and hats in a variety of styles. Sixteen year-old Mary O’Shannassy was wearing a similarly 'loud' outfit in 1871. She had been placed in indentured service under Victoria’s industrial schools laws, either because she had been deemed neglected or at risk of harm, or because she was wanted by police after running away. $^{34}$

O’Shannassy might well have been referred to as a 'larrikiness' by observers. This colonial slang term was often applied to adolescent girls with a history of disorderly behaviour. It had a similar resonance to 'Bowery girl' in New York. ${ }^{35}$ Numerous caricatures in the Melbourne Punch depicted 'larrikinesses' in audaciously street-smart dress in the 1870s (Fig. 2). Though they presumably exaggerated the gaudiness of delinquent young women's dress, police descriptions of adolescent runaways suggest they were not entirely off the mark. O'Shannassy, for one, wore a 'new wincey skirt with scarlet robing, a purple woollen pelerine, white straw hat trimmed with blue ribbon and black lace', and carried a black silk parasol. ${ }^{36}$

\section{FLASH DRESS AND FASHION: A COMPLEX RELATIONSHIP}

Historians tell us that a 'consumer society' first started to emerge in western Europe in the 'long eighteenth century': the years spanning the late 1600s and early 1900s. By this they mean that an economy and way of life emerged that revolved around buying and selling goods for money rather than bartering or subsistence production. ${ }^{37}$ After technological innovations began to allow for the mass manufacture of goods in the late nineteenth century, a great acceleration of consumer capitalism occurred, spurred on by new methods for the promotion of goods to a wider market. ${ }^{38}$ Scholars talk of a 'democratization of clothing' or even a 'democratization of fashion' as a consequence of these developments. A more socially diverse range of people were able to afford new clothes, they tell us, and to at least aspire to look desirably 'up to date'. ${ }^{39}$

As the Brisbane journalist's reference to 'fallen' women wearing costumes of the 'very latest cut' suggests, flash women were participants in the so-called 
democratization of clothing and fashion. In the early 1870s, for example, police gazettes described disreputable women wearing dresses with panniers. A pannier was a hoop petticoat that belled out at the hips while remaining flat at the front, a very fashionable item at that time. In 1873, twenty-seven year-old prostitute, Jane Tucker, alias Ross, wanted for assault, was wearing a 'brown dress with pannier, tall black hat with white feather, and a pink fur'. ${ }^{40}$ Wanted for the theft of a dress in 1874 , seventeen-year-old Kate Johnstone, lately a 'ballet girl' at a Bourke Street variety hall, wore a 'black lustre dress with pannier' ${ }^{41}$ From the 1890s, too, large hats and separates (blouses and skirts) were popular not only among disorderly women but with female consumers more generally. ${ }^{42}$ Echoing a look then on display in department store windows and actresses' cartes des visites, sixteen year-old runaway Mildred Galbraith wore a scotch tartan bodice, black skirt and a leghorn hat with black feathers in $1895 .^{43}$

Prostitutes going on shopping sprees with the proceeds of theft provide other examples of flash women taking part in the intensifying consumerism of their day. After robbing miner Frederick North in 1881, Melbourne prostitute Mary Horan headed directly to a city clothing store and bought a new readymade hat, cashmere dress and shawl. ${ }^{44}$ Brisbane’s Honora O’Donnell also went shopping for clothes after stealing fifteen pounds from her brothel madam in 1872. She bought a pair of earrings from a shop in Queen Street, Brisbane's major retail precinct, and then spent nine pounds on a brown moire antique dress from a recently-opened department store. ${ }^{45}$ It is significant, however, that women such as O'Donnell only made these purchases after engaging in theft. This highlights the fact that their small means restricted the extent to which they could participate in the 'democratization of fashion'. They were hardly the middle-class department-store shoppers that historians such as Gail Reekie and Erika Diana Rappaport have written so much about. Nor were they the shopgirls and upmarket chorus-girls featured in other work on female participation in fin de si 'modernity'. 46

Quite apart from the question of their limited means, flash women's interest in street style placed them in a complicated relationship to fashion. As anthropologist Daniel Miller tells us, style is concerned with the expression of individual creativity and bodily mannerisms. Unlike fashion, the collective following of a sartorial trend, style is as much about the way clothes are worn as the clothes themselves. ${ }^{47}$ Street style in 
particular had different priorities to fashion at this time. Long before it became an inspiration for high fashion, it valorized nonconformity to broadly accepted feminine conventions as well as an eclectic look. Plenty of manifestations of flash style incorporated elements that were distinctly unfashionable because of this. They incorporated things that had acquired an air of streetwise audacity because they resisted normative ideas about how women should dress and behave. To illustrate this, we now turn to three of these unfashionable elements: short hair, short skirts and tattoos.

\section{UNFASHIONABLE ELEMENTS}

Since it could cost nothing to dress or cut one's hair, it is not surprising that hair played an important role in flash style. An unknown Brisbane woman suspected of pickpocketing in 1893 was reported to have hair 'very much crimped'. Witnesses told police that she had the 'appearance of a flash prostitute'. ${ }^{48}$ Examples of prostitutes with peroxided hair also began to appear in police gazettes during the Edwardian years. ${ }^{49}$ Throughout the 1870 to 1910 period, too, female prisoners frequently appeared in mugshots with short, often badly-cut fringes. ${ }^{50}$ Guilty of 'idle and disorderly' behaviour in the inner-Melbourne suburb of Collingwood in 1880, the 'brazen larrikiness' Elizabeth Pollock was photographed with one such fringe. ${ }^{51}$

Some disreputable women went further than Elizabeth Pollock by cutting off all their hair. Unruly adolescent girl Elizabeth Jellett was one of these. She was seen in Melbourne's Little Bourke Street in 1875 wearing a green ribbon at her neck, a brown straw hat with a black veil and short hair. ${ }^{52}$ A decade later, police noted that fifteen year-old Sydney runaway Emma McGrath wore her 'hair cut short and fringed' ${ }^{53}$ The phrase 'hair cut short' appeared regularly in other descriptions of wanted women between the 1880s and the end of the Edwardian era. ${ }^{54}$ In 1903, too, a caricature of Edith Foley, a seventeen-year-old Melbourne girl charged with vagrancy, showed her sporting cropped hair and a newspaper-boy's cap. At the time, Foley was said to be uncontrollable on account of her 'love of flash dress and fast companions' ${ }^{55}$

It is possible that women such as Kate Bolton (Fig. 3) decided to sell their hair for wigs or had it removed by staff in penal or welfare institutions, whether as a punishment or because it was infested with lice. ${ }^{56}$ Yet even if this was the case, it seems that these women wore their short hair with a certain brazenness and incorporated it into flash 
feminine style. At a time when women were expected to have long hair and to wear it up in a carefully disciplined, dressed way, these women would have made a startling impression on the street with their shorn heads - especially if they teamed this boyish look with the 'flaunting manners' of a flash girl. ${ }^{57}$

Another simple way for delinquent girls to accomplish a daring look was to wear provocatively shortened skirts. It was not unusual for working-class women to wear skirts short enough to show their ankles in this period, allowing greater ease of movement. ${ }^{58}$ Pre-adolescent girls also wore short skirts, but around fourteen switched to long dress as part of the transition to puberty. ${ }^{59}$ Police records suggest, however, that a number of riotously-behaved women aged between their mid-teens and early thirties wore their hemlines significantly shorter: somewhere between mid-calf and the knee. ${ }^{60}$ Adolescent girls at Sydney’s Biloela Industrial School ripped off their regulation dresses to the knee in the early 1870s. ${ }^{61}$ A pair of Brisbane 'larrikinesses' sought to achieve a similar look in 1885 simply by tucking up their skirts. ${ }^{62}$ Likewise 'gangs of short-frocked sirens' were reported roaming the streets of Brisbane in the early years of the next century. ${ }^{63}$

The obvious explanation for women raising their hemlines was that they were signalling sexual availability (Fig. 4). This was certainly what onlookers assumed about American prostitutes with short skirts in the early 1900s. ${ }^{64}$ Yet the style could attract ridicule rather than sexual interest. The Brisbane larrikinesses who tucked up their skirts in 1885 were mocked by a male and female acquaintance in the street, leading to a punch-up and criminal proceedings. ${ }^{65}$ In the 1890s Melbourne brothel-keepers were also found urging adolescent recruits to stop wearing short skirts. ${ }^{66}$ They may have done this to avoid police scrutiny, in an effort to make the girls appear older than they were. It is possible, however, that raised hemlines were adopted by young women more as a sign of rowdy flashness than a tool of the prostitute's trade: more to draw admiration from their peers on account of its audacity than a way to be alluring to men. ${ }^{67}$

Tattooing was another important and decidedly unfashionable aspect of flash style. Admittedly, it enjoyed a brief vogue among aristocratic women in England during this period. ${ }^{68}$ Disreputable women in Europe had worn tattoos long before this, however, and the same applied in turn-of-the-century Australia. ${ }^{69}$ Australian prison records reveal that female inmates often bore insignia on their arms, and sometimes their torsos as 
well. Hearts, shields, crosses, chains and human figures were popular designs. ${ }^{70}$ Most common was the inscription of initials and declarations of love - often for more than one lover. Prostitute pickpocket Bella Brady had the initials R.F. and also L.L. tattooed on her right arm; her left arm bore the inscriptions 'D.S \& L' and also 'I love L. L. A. ${ }^{.71}$ Twenty-seven year old Rose Trieshmann, a Brisbane prostitute who wore her skirt 'rather short', had a woman, heart, shield and the inscription "I love H.W" tattooed on her right arm in 1899. She was living with a man known as 'Nigger' McGuire at the time. ${ }^{72}$ Another Brisbane prostitute, Ada De Lacey, described by police as a 'half-caste' Aborigine, had a tattoo that read 'I love Joe McDonald' on her left arm. ${ }^{73}$

\section{FLASH DRESS AND SOCIALITY}

In many ways, tattoos were the quintessential example of flash style. In the first place, they were redolent of criminality. Frequently, too, they were flamboyant in design. ${ }^{74}$ More significantly, they made use of an iconographic code - a secret language like the 'flash' vocabulary - that conveyed meanings that only insiders understood. Work by Hamish Maxwell-Stuart on tattoos among male convicts transported to Australia, for instance, shows that while anchors symbolized hope, their incorporation into different designs could subtly alter a tattoo's meaning. A convict's initials appearing with an anchor thus meant 'I have hope'; an anchor and a woman holding a pair of scales meant 'I have hope in justice'; while a convict's initials with an upside-down anchor meant 'I have lost all hope' ${ }^{75}$ Since one needed to know the language of tattooed symbols to understand these meanings, tattoos reinforced a sense of community among those 'in the know'. Usually hidden beneath clothes, revealed only to intimates, and sometimes commemorating these liaisons, they suggest that flash style was crucially involved in the business of forging and sustaining personal relationships.

If the secret language of tattoos cultivated a sense of being 'in the know' among disreputable types, then the physical experience of acquiring a tattoo also helped to consolidate relationships. One can imagine Rose Treishmann asking a female associate to give her a tattoo one night, and then sharing a slug of rum before beginning the ordeal. Other women perhaps asked friends to join them on trips to a tattooist-for-hire, telling jokes to distract from the pain. Shopping for clothes together was another way in which flash women cultivated sociality. A Brisbane prostitute thus convinced a male 
client to buy new muffs for herself and a female friend in $1882 .{ }^{76}$ Melbourne prostitutes Florence Martin and Susan Pettit similarly bonded over a shopping trip in 1881. After robbing a client they each bought a readymade dress together at a city store. ${ }^{77}$

Borrowing items of dress might be another way for flash women to reinforce social bonds. This was especially evident among those who lived together, whether in brothels or other shared housing. In 1895, for instance, Catherine Turner asked her colleague Mary Ann Dunn if she could borrow her jacket 'for luck' before she headed out to solicit custom for the night. Such requests did not always result in greater intimacy Turner's relationship with Dunn soured after she returned the jacket in poor condition a few days later. ${ }^{78}$ There were many civil cases before the courts in which disreputable women contested each other's ownership of clothes. These cases do not just point to conflict over dress, however, but to the fact that a culture of shared or borrowed dress existed among the women concerned. ${ }^{79}$

In a discussion of dress practices in nineteenth-century Philadelphia, Kathryn Wilson shows how middle-class women forged social networks through the production and design of dress. These women shared information about the latest fashions as well as tips about where to source fabrics, about the best and most economic custom dressmakers, and how to sew or alter one’s own clothes. According to Wilson, such 'woman-centred contexts' allowed middle-class Philadelphian women to engage in 'active renegotiation of fashion design'. Their social networks 'fostered scepticism and resistance' rather than just conformity to the latest fashions and normative gender ideals. $^{80}$

Social networks were even more important to flash women than to those discussed by Wilson. Because of their more limited means, they had more need to rely on cooperation with peers to produce their look. They did not just share tips about shopping and sewing, but also borrowed each other's clothes and made joint purchases after pooling the proceeds of theft. Possibly they also helped to give each other tattoos and haircuts. Obviously, too, disreputable women were involved in a much more overt resistance to gender norms than their middle-class counterparts. Even when they wore fashionable items they incorporated them into an aesthetic that prioritized eclecticism and brazenness over looking acceptably feminine and 'up to date'. 


\section{FLASH DRESS AND MODERNITY}

As the titles of works such as Fashion and Modernity, Accessories to Modernity and Adorned in Dreams: Fashion and Modernity suggest, the term 'modernity' looms large in work on dress and fashion between the mid 1800s and mid 1900s. ${ }^{81}$ The best uses of it occur when scholars define and employ it in quite specific ways. Some historians writing about the interwar period investigate the particular meanings women gave to the term 'modern'. Since it was a word regularly appearing in everyday speech in that period, they use it to explore the interpretations interwar women gave to their own lives. ${ }^{82}$ Unfortunately, however, the term 'modernity' is not often used to such specific ends. Any number of scholars speak vaguely of societies entering into a state of 'modernity' after becoming sufficiently 'modernized'. They tell us that things took place 'in modernity' instead of just telling us that things took place 'in the twentieth century' or 'in capitalist society', so that the term has come to be used with what Timothy Burke calls 'near-meaningless abandon'. On occasion, too, scholars interested in modern consumption rely on the notion of a rupture between a traditional state of being and a modern one: a point at which a given society shifted from one to the other. ${ }^{83}$

'Modernity' is sometimes used in the relevant literature in another sense: that is, to refer to 'the way that modernization infiltrates everyday life and permeates sensibilities' at different moments in history. ${ }^{84}$ This use of the term has appealed particularly to feminist scholars since the mid 1990s. The reason for this is that its focus on everyday life and sensibilities allows them to emphasize women’s agency. During the 1980s the majority of feminist scholars were pessimistic about the effects of modernization on women. They argued that women had been manipulated and objectified by the acceleration of consumer capitalism around the turn of the century. ${ }^{85}$ In the 1990s, however, feminist scholars became increasingly keen to foreground women's agency in the face of modernizing developments.

One of the most influential feminist works signalling a shift away from pessimistic assessments of modernization was Rita Felski’s The Gender of Modernity (1995). It emphasized the ways in which women used 'modern' commodities such as fashion to act and imagine themselves in new ways. Women were able to feel the frisson of pleasure that came from dressing for the first time in a sexual way, she suggested. Once department stores and pleasure resorts were built in city centres, they were also able to 
move into urban spaces once considered a masculine domain. The oft-made assumption of a rupture between a past state of being and a new one underpinned Felski's arguments here. Women were able to realize new possibilities for themselves in this period, she claimed, because 'the advent of mass production and distinctively modern retailing strategies began to dramatically alter the everyday fabric of social relations between people and things, ${ }^{86}$

American historian Kathy Peiss is another feminist who foregrounds women's agency amid the expansion of consumer capitalism. Throughout her career she has argued that women forged a 'new sense of female self' through their consumption of cosmetics, mass-produced fashions and commercial amusements in the decades following 1870. 'Independent, athletic, sexual and modern', this new sense of self would come to full flower in the figure of the bob-haired, scarlet-mouthed Modern Girl of the 1920s. Peiss has been particularly concerned to demonstrate working-class women's role in evolving this new femininity. Her work challenges 'trickle-down' theories of fashion and cultural change: those asserting that behaviours and styles originate with an elite before being adopted by people further down the social scale. Far from being followers of elite fashion, she tells us, turn-of-the-century working-class women were actually pioneers of the femininity later represented by the Modern Girl. Long before their middle and upper-class sisters, they were experimenting with sexualized forms of display and unchaperoned trips to inner-urban dance halls. ${ }^{87}$

Both Peiss's and Felski's approach to women and modern consumption have been extraordinarily influential in feminist scholarship. It is now common to find scholars searching for ways to show that women made themselves into 'modern' subjects even if they did not use that term to describe themselves. Some look for evidence of late nineteenth-century women adopting the persona of the flâneuse: that is, the female equivalent to the male stroller or flâneur often considered to be a quintessential embodiment of modernity. ${ }^{88}$ The implication of this work is that the only way we can demonstrate female agency in the face of large-scale processes in history is by discovering aspects of 'modernity' in their practices and identities. As our discussion of flash women's 'material strategies' makes clear, however, this is not in fact the case. ${ }^{89}$ One can just as easily show that women demonstrated agency by maintaining continuities with older forms of disreputable femininity as by anticipating new ones. 
Many flash women belonged to 'the oldest profession in the world'. They were tattooed prostitutes with obvious links to the convict women belonging to flash mobs in convict-era Australia - if not also to flash girls from the previous century. If a woman like Ada de Lacey had 'I love Joe McDonald' inscribed on her skin and wandered free around the streets of Brisbane by night in the 1890s, it is unlikely to have been because of a 'modern' interest in romance, or because she was feeling the newfound freedom of moving into a masculine domain. Tattooing and walking the streets were longstanding practices among disreputable women by that time, after all. The way these women reinforced social bonds also involved 'old' practices such as borrowing and lending clothes as much as participation in 'new' shopping sprees.

Claims of dramatic alterations in the relationship between people and things between 1870 and 1910 overstate what was happening at the level of individual subjectivity and everyday life. These grand assertions about the effects of modernization gloss over the subtle accommodations between older and newer elements at work at the time. The flash aesthetic was a perfect illustration of this. We can see the adaption of older strategies to meet new circumstances in the case of the reformatory girl who renovated a drab second-hand dress by hand-sewing new red plush along its hemline - or otherwise in the case of a prostitute who teamed a new readymade cashmere dress with tattoos, and perhaps a stolen ring to boot. Yet it was not just flash women who dressed themselves via a mix of material strategies. While flash women may have been unusual in their embrace of an eclectic aesthetic, Barbara Burman's work on home dressmaking in Edwardian England shows that most people in the era relied on a hotchpotch of methods to dress themselves.

The advent of mass-manufactured readymade clothing and the related development of a fashion industry did not bring about a sudden alteration of people’s way of life in Edwardian England. On the contrary, Burman demonstrates that the 'wide variety in clothing and consumption practices which had for so long characterized most households' continued. For a start, plenty of working and middle-class women continued to produce their household's clothes at home. Many also continued to rely on hand-me-downs and second-hand purchases. It was not until the 1920s that the quality of readymade clothing improved sufficiently for it to be considered a viable option by a substantial portion of the populace - and even then mass-produced goods were only one 
option among many when it came to dress. ${ }^{90}$ These observations are arguably even more applicable to Australia than England. It was not until the Australian colonies federated in 1901 and passed laws aimed at abolishing 'sweating' that concerted investment in mechanization even began to occur in the clothing and footwear trades. Before then, the production of clothes and shoes was largely small-scale and poorly capitalized, with obvious implications for the ways in which dress was produced and consumed. $^{91}$

We are obviously not trying to suggest here that no changes were taking place 'in the scenario of production and consumption' between 1870 and 1910. As Burman points out, 'traditional' small-scale practices such as home dress-making were starting to be contested by large-scale commercial interests by that time. ${ }^{92}$ Prostitution was similarly changing. As Australian historian Judith Allen shows, it began to undergo a process of 'proletarianization' from the start of the twentieth century. ${ }^{93}$ The concept of 'flash' was being commodified in popular culture, no doubt with some influence on the ways in which a flash look was enacted on the street. It is quite likely that the line of influence also ran the other way. Aspects of flash girls' on-the-street style may have influenced popular representations of flash culture, in other words. By this means, flash style may even have had an effect on mainstream fashions over time - affecting the uptake of shorter skirts and hair, for example - much as street styles now influence mainstream and high fashion today.

While we have no difficulty with the notion that significant changes in the scenario of production and consumption were underway, we take issue with the idea that these changes brought about 'modernity' understood as a state of being into which some female subjects, or society more generally, entered at the turn of the century. Understood in this way, the concept of modernity is inevitably predicated on an exaggeration of the effects of 'modernizing' forces on individual subjectivities, customs and everyday life. We are also convinced that investigating 'modernity' or the new presents a distorted view of any moment in history. This is because it encourages a narrow focus on emergent practices or sensibilities while glossing over others that were long-held or on the wane. Thinking about flash women between 1870 and 1910 certainly requires us to think about a range of emergent and long-held practices, some harking back to the eighteenth century and others anticipating later decades in the 
twentieth. It is for this reason that it would be a mistake to categorize flash women as proto-'Modern Girls' in spite of the fact that some were wearing short skirts and hair long before women in 'straight' society. As we said at the outset, one might just as easily categorize them as the inheritors of convict-era sensibilities, or of the theatrical flair evident among elements of the 'criminal classes' in eighteenth-century England, as refer to them as early adopters of modern feminine styles.

\section{CONCLUSION}

We are hardly alone of course in calling into question the usefulness of the concept of 'modernity'. Anthropologists of consumption have long rejected the assumption of a radical turning-point between 'traditional' consumption regimes (in which people were primarily users of goods) and 'modern' ones (in which they were primarily consumers of commodities).$^{94}$ Plenty of historians have also rejected this assumption - Barbara Burman being a pertinent example. In recent years, cinema scholars been similarly forced to revise the exaggerated claims about the notion of modernity once made by others in the field. Back in the 1990s, many cinema historians argued that the advent of film technology heralded radically new and modern ways of being at the turn of the twentieth century. This 'modernity thesis' came in for heavy criticism in the new millennium, so that historians of early cinema now offer much more careful discussions of the relationship between film and modernization, and others question whether the notion of modernity has any heuristic value at all. Many scholars of gender and consumption are still preoccupied with the search for modern sensibilities and practices in the late nineteenth or early twentieth centuries, however - and it is for this reason that we have engaged in our own critique here.

In sum, then, we consider the valorization of the 'modern' in scholarship on turn-ofthe-twentieth-century fashion and gender to be problematic for two key reasons. In the first place, it adopts what E. P. Thompson called the 'enormous condescension of posterity'. It suggests that the only things worth paying attention to in the past were those that anticipated later developments. ${ }^{95}$ In the second place, it presents a skewed vision of past phenomena. It entices us to brand certain processes as 'new' in order to make them worthy of scholarly attention, glossing over the fact that they often possess quite lengthy histories. The culture of sexualized display and hedonism cultivated by 
working-class women in the late nineteenth century is an obvious example of this. As even a cursory glance at 'flash’ culture suggests, its female participants had taken an interest in flamboyant self-statement and hectic urban pleasures long before the acceleration of consumer capitalism in the late 1800s. In their eagerness to talk about specifically modern forms of femininity, many scholars have thus overstated the extent to which female interest in sexualized display was a new development at the turn of the century.

Scholars of fashion and feminine consumption have also tended to underplay the multiplicity of dress practices in existence in the late nineteenth and early twentiethcentury period. In its conspicuous eclecticism, flash street style provides a potent example of this multiplicity. To produce a flash look, disreputable women sourced clothes from a variety of places and through diverse methods. They bought fashionable items from brand-new department stores as well as flea-ridden markets, acquired tattoos and hand-me-downs from friends as well as commissioning new items from tailors on instalment plans. Flash women's dress was thus a palimpsest of the hand-made, machine-made, shop-bought, borrowed, stolen and renovated between 1870 and 1910: a complex collection of parts that defy understanding through the concepts of 'tradition' or 'modernity'.

\section{Alana Piper ...}

\section{Melissa Bellanta ...}

\section{NOTES AND REFERENCES}

1 Evidence of Sergeant James Dalton, 'Report from the Select Committee upon a Bill for the Prevention of Contagious Diseases', Victorian Parliamentary Papers, 1878, vol. 1, p. 16; Truth (Melbourne), 13 June 1903, p. 6.

2 John Stanley James, The Vagabond Papers, Melbourne, 1969, pp. 231-2; Sydney Morning Herald, 13 July 1870, p. 7. 
3 Ulrich Lehmann, 'L'Homme des Foules, Dandy, Flâneur: Fashion and the Metropolis 1850-1940', in The Fashion History Reader: Global Perspectives, ed. Peter McNeil and Giorgio Riello, New York, 2010; Andrew Davies, The Gangs of Manchester: Britain’s First Youth Cult, Preston, 2009, pp. 18, 19, 22-4; Melissa Bellanta, Larrikins: a History, St Lucia, 2012, chap. 5.

4 Raelene Frances, Selling Sex: a Hidden History of Prostitution, Sydney, 2007, p. 136; Judith R. Walkowitz, Prostitution and Victorian Society: Women, Class, and the State, Cambridge, 1980, pp. 25-6; Ruth Rosen, The Lost Sisterhood: Prostitution in America, 1900-1918, Baltimore, 1982, pp. 106-7; Alain Corbin, Women for Hire: Prostitution and Sexuality in France after 1850, Cambridge, 1990, pp. 59; 82; Donna J. Guy, Sex and Danger in Buenos Aires: Prostitution, Family, and Nation in Argentina, Lincoln, 1991, pp. 19, 49; Mariana Valverde, 'The Love of Finery: Fashion and the Fallen Woman in Nineteenth-Century Social Discourse', Victorian Studies 32: 2, Winter 1989; Julia Laite, Common Prostitutes and Ordinary Citizens: Commercial Sex in London, 1885-1960, Basingstoke and New York, 2012, pp. 39, 84.

5 Erika Diana Rappaport, Shopping For Pleasure: Women in the Making of London's West End, Princeton, 2001; Lisa Tiernan, Marianne in the Market: Envisioning Consumer Society in Fin-de-Siècle France, Berkeley, 2001; Mica Nava, Visceral Cosmopolitanism: Gender, Culture and the Normalisation of Difference, New York, 2007.

6 Nan Enstad, Ladies of Labor, Girls of Adventure: Working Women, Popular Culture and Labor Politics at the Turn of the Century, New York, 1999; Kathy Peiss, Cheap Amusements: Working Women and Leisure in Turn-of-the-Century New York, Philadelphia, 1986, chap. 3; and Peiss, 'Girls Lean Back Everywhere’ in The Modern Girl Around the World Research Group, The Modern Girl Around the World: Consumption, Modernity and Globalization, Durham, 2008, pp. 351-3.

7 Raelene Frances, ‘Gender, Working Life and Federation’, in Working Life and Federation, 1890-1914, ed. Mark Hearn and Greg Patmore, Annandale, 2001.

8 Dalton, 'Report from the Select Committee', p. 16.

9 James Hardy Vaux, 'A Vocabulary of the Flash Language', in The Memoirs of James Hardy Vaux, ed. Noel McLachlan, London, 1964, pp. 240-1. 
10 Robert Jordan, The Convict Theatres of Early Australia, 1788-1840, Hatfield, 2003, pp. 13-14; Kasia Boddy, Boxing: a Cultural History, London, 2008, p. 58; Patricia Cline Cohen with Timothy J. Gilfoyle and Helen Lefkowitz Horowitz, The Flash Press: Sporting Male Weeklies in 1840s New York, Chicago and Bristol, 2008.

11 Jordan, The Convict Theatres, p. 13; John Styles, The Dress of the People: Everyday Fashion in Eighteenth-Century England, New Haven and London, 2007, p. 198.

12 Styles, Dress of the People, pp. 199, 210; Beverly Lemire, 'The Theft of Clothes and Popular Consumerism in Early Modern England’, Journal of Social History 24 2, 1990; Lemire, 'Peddling Fashion: Salesmen, Pawnbrokers, Taylors [sic], Thieves and the Second-Hand Clothes Trade in England, 1700-1800', Textile History, 22: 1, 1991; Graham White and Shane White, Stylin': African American Expressive Culture From Its Beginnings to the Zoot Suit, Ithaca, 1998, p. 13; Rebecca Earle, ““Two Pairs of Pink Satin Shoes!!” Race, Clothing and Identity in the Americas (17th and 19th centuries)', History Workshop Journal 52: 1, autumn 2001.

13 Kay Daniels, 'The Flash Mob: Rebellion, Rough Culture and Sexuality in the Female Factories of Van Diemen's Land', Australian Feminist Studies 18, 1993; Thomas Livingstone Mitchell, Journal of an Expedition into the Interior of Tropical Australia, London, 1848, pp. 419-20; William Augustus Miles, Registry of Flash Men, NRS3406, State Records New South Wales, srwww.records.nsw.gov.au/ebook/flashmen.asp, accessed 31 Aug. 2012.

14 Gregory Dart, ““Flash Style”: Pierce Egan and Literary London, 1820-28’, History Workshop Journal 51: 1, spring 2001; Lyn Pykett, 'The Newgate Novel and Sensational Fiction, 1830-1868' in The Cambridge Companion to Crime Fiction, ed. Martin Priestman, Cambridge, 2003, p. 21; Bellanta, Larrikins, chap. 5.

15 New South Wales Police Gazette (hereafter NSWPG), 1891, p. 249.

16 NSWPG, 1901, p. 56; Queensland Police Gazette (hereafter QPG), 1901, p. 209. 17 NSWPG, 1875, p. 54; QPG, 1875, p. 133; QPG, 1880, p. 70; QPG, 1891, p. 121; Victoria Police Gazette (hereafter VPG), 1895, p. 85; QPG, 1901, p. 131.

18 Photographs in the Freeman Studio Collection at the State Library NSW, currently being digitized: finished yet? 
http://acms.sl.nsw.gov.au/item/itemDetailPaged.aspx?itemID=825450, accessed 20 Sept. 2012.

19 Australian Etiquette, or, the Rules and Usages of Best Society in the Australasian Colonies, Together with Their Sports, Pastimes, Games and Amusements, Sydney, 1885, pp. 350-3.

20 Truth (Brisbane), 3 Feb. 1907, p. 2.

21 Truth (Melbourne), 10 March 1906, p. 3.

22 Frances, Selling Sex, p. 132; Raymond Evans, “"Soiled Doves”: Prostitution in Colonial Queensland', So Much Hard Work: Women and Prostitution in Australian History, ed. Kay Daniels, Sydney, 1984, pp. 137-8.

23 Queensland State Archives (hereafter QSA), Series 6300 Deposition and Minute Books Police Court, Item ID 970990, 26 Nov. 1890, Police v. Margaret Savage; Brisbane Truth, 5 April 1903, p. 3; Frances, Selling Sex, p. 129.

24 Margot Riley, 'Cast-Offs: Civilisation, Charity or Commerce? Aspects of Second Hand Clothing Use in Australia, 1788-1900' in Old Clothes, New Looks: Second Hand Fashion, ed. Alexandra Palmer and Hazel Clark, http://dx.doi.org.ezproxy.library.uq.edu.au/10.2752/9781847888815/OCNL0010. This website needs library sign-in - cut?

25 Bronwyn Labrum, 'Hand-Me-Downs and Respectability: Clothing and the Needy', in Looking Flash : Clothing in Aotearoa New Zealand, ed. Bronwyn Labrum, Fiona McKergow and Stephanie Gibson, Auckland, 2007.

26 VPG, 1900, p. 69.

27 We say this on the basis that the production of clothes at home was crucial to the domestic economy of most Australian families, and that the clothing trade was one of the biggest employers of working-class women: Margaret Maynard, Fashioned From Penury: Dress as a Cultural Practice in Colonial Australia, Cambridge, 1994, pp. 126 9.

28 Brisbane Courier, 7 June 1887, p. 6.

29 Deb Salisbury, Elephant's Breath and London Smoke: Historical Colour Names, Definitions and Uses, Neustadt, Ontario, 2009, p. 75.

30 Jonathan Prude, 'To Look Upon the "Lower Sort”: Runaway Slave Ads and the Appearance of Unfree Laborers in America, 1750-1800', Journal of American History 
78, 1991; Karen Tranberg Hansen, Salaula: the World of Secondhand Clothing and Zambia, Chicago and London, 2000.

31 VPG, 1895, p. 130.

32 Argus (Melbourne), 8 Jan. 1887, p. 13.

33 Public Records of Victoria (hereafter PROV), VPRS 516/P1 Central Register of Female Prisoners, Register 12, 6753, Mary Jeanne Sinclair; PROV, VPRS 516/P1, Register 9, 5431, Jane Kirkpatrick; PROV, VPRS 516/P1, Register 9, 5424, Polly Larkins; PROV, VPRS 516/P1, Register 12, 6664, Ada Capewell and Lily Walker. 34 Robert van Krieken, Children and the State: Social Control and the Formation of Australian Child Welfare, North Sydney, 1992, pp. 68-72.

35 Bellanta, Larrikins, chap. 2; Christine Stansell, City of Women: Sex and Class in New York, 1789-1860, New York, 1986, pp. 93-4.

36 VPG, 1871, p. 171.

37 Paul Glennie, ‘Consumption Within Historical Studies’, in Acknowledging Consumption: a Review of New Studies, ed. Daniel Miller, London and New York, 1995, pp. 165-7.

38 Christopher Breward, The Culture of Fashion: a New History of Fashionable Dress, Manchester, 1995, p. 147; Cynthia Cooper, 'The Victorian and Edwardian Eras: 1860-1910’, in The Fashion Reader, ed. Linda Welters and Abby Lillethun, 2nd edn, Oxford, 2007.

39 Cooper, 'The Victorian and Edwardian Eras', p. 34; Giorgio Riello and Peter McNeil, 'Between Luxury and Leisure: the Nineteenth Century’, in The Fashion History Reader, p. 269.

40 VPG, 1873, p. 300; see also VPG, 1873, p. 279; VPG, 9 March 1875, p. 54; Elizabeth Scandrett, Breeches and Bustles: an Illustrated History of Clothes Worn in Australia, Lilydale, 1978, p. 62; Alexandra Joel, Best Dressed: 200 Years of Fashion in Australia, Sydney, 1984, pp. 29-31.

41 VPG, 1874, p. 88.

42 Separates: QPG, 1896, p. 184; QPG, 1899, p. 414; VPG, 1900, p. 41; VPG, 1905, p. 44. Large hats: VPG, 1895, p. 139; VPG, 1895, p. 167; QPG, 1896, p. 76; QPG, 1899, p. 243; QPG, 1904, p. 479. Scandrett, Breeches and Bustles, pp. 118, 142. 43 VPG, 1895, p. 139. 
44 PROV, VPRS 30/P0 Trial Briefs, Unit 559, 1880/9, Regina v. Mary Horan. 45 Queenslander, 28 Sept. 1872, p. 9.

46 Gail Reekie, Temptations: Sex, Selling and the Department Store, St. Leonards NSW, 1993; Rappaport, Shopping For Pleasure; Lise Shapiro Sanders, Consuming Fantasies: Labor, Leisure and the London Shopgirl, Columbus, 2006; Angela Woollacott, To Try Her Fortune in London: Australian Women, Colonialism and Modernity, Oxford, 2001.

47 Daniel Miller, 'Style and Ontology in Trinidad', in Consumption and Identity, ed. Jonathan Friedman, Amsterdam, 1994.

48 QPG, 1893, p. 236.

49 Truth (Brisbane), 31 May 1903, p. 5; Truth (Melbourne), 7 Nov. 1903, p. 3. On peroxided hair, see Caroline Cox and Lee Widdows, Hair and Fashion, London, 2005, pp. 36-8.

50 PROV, VPRS 516/P1, Register 10, 5521, Mary Hogan; PROV, VPRS 516/P1, Register 10, 5869, Annie Hicks; PROV, VPRS 516/P1, Register 12, 6435, Annie Henry; NSWPG, 1901, p. 48.

51 Collingwood Observer, 28 Oct. 1880, p. 4; PROV, VPRS 516/PO, Unit 8, 4691, Elizabeth Pollock.

52 VPG, 1875, p. 216.

53 NSWPG, 1886, p. 229.

54 QPG, 1885, p. 120; QPG, 1887, p. 69; $Q P G, 1887$, p. 367; QPG, 1887, p. 379; $Q P G, 1887$, p. 429; $Q P G, 1900$, p. 189; $Q P G, 1904$, p. 119; $Q P G, 1908$, p. 3; $Q P G$, 1908, p. 215.

55 Truth (Melbourne), 3 June 1903, p. 6.

56 Bronwyn Dalley, 'From Demi-Mondes to Slaveys: Aspects of the Management of the Te Oranga Reformatory for Delinquent Young Women, 1900-18', in Women in History 2, ed. Barbara Brookes, Charlotte Macdonald and Margaret Tennant, Wellington, 1992, pp. 161-2.

57 Royce Mahawatte, 'Hair and Fashioned Femininity in Two Nineteenth-century Novels', in Hair: Styling, Culture and Fashion, ed. Geraldine Biddle-Perry and Sarah Cheang, Oxford, 2008. 
58 Valerie Steele, Fashion and Eroticism: Ideals of Feminine Beauty from the Victorian Era to the Jazz Age, New York, 1985, p. 114.

59 Maynard, Fashioned From Penury, p. 81.

60 VPG, 1900, p. 161; QPG, 1900, p. 131. NSWPG, 1905, p. 399.

61 Evidence of Caroline Brackenregg, Report of the Royal Commission on Public Charities, Parliamentary Reports, NSW Legislative Assembly, 1873-4, Report No. 2, p. 106; anything to add? Or should semi-colon be full stop?

62 Bellanta, Larrikins, p. 45.

63 Truth (Brisbane), 22 March 1903, p. 1.

64 Mara L. Keire, 'Dope Fiends and Degenerates: the Gendering of Addiction in the Early Twentieth Century’, Journal of Social History 31: 4, 1998, pp. 813-4.

65 Bellanta, Larrikins, p. 45.

66 PROV, VPRS 30/P0 Trial Briefs, Unit 905, 1892/548a, Regina v. Amy Cramer; PROV, VPRS 30/P0 Trial Briefs, Unit 951, 1893/577, Regina v. Annie Sullivan.

67 For an extended version of this argument about the significance of female peers to disorderly adolescent girls, see Bellanta, Larrikins, chap. 2.

68 Jordanna Bailkin, 'Making Faces: Tattooed Women and Colonial Regimes', History Workshop Journal, 59: 1, spring 2005, p. 34.

69 Jane Caplan, ““Educating the Eye”: the Tattooed Prostitute’, in Sexology in Culture, ed. Lucy Bland and Laura Doan, London, 1998.

70 PROV, VPRS 516/P1 Central Register of Female Prisoners; QSA, Register of Female Prisoners, Valley Gaol, January 1902-October 1903, 17303; QSA, Register of Prisoner Descriptions, Valley Gaol, January 1902-October 1903, 2948; QSA, Alphabetical Register of Female Prisoners, Brisbane Prison, 1903-1904, 2905; QSA, Female Register of Brisbane Prison Admission, 1906-1912, QSA, 2923.

71 QSA, Female Register of Brisbane Prison Admission, 1906-1912, QSA, 2923. 72 QPG, 1899, p. 468.

73 QPG, 1897, p. 84.

74 Jane Caplan, “'Speaking Scars”: the Tattoo in Popular Practice and Medico-Legal Debate in Nineteenth-Century Europe,” History Workshop Journal, 44: 1, autumn 1997, pp. 120-1. 
75 Hamish Maxwell-Stewart, 'The Search for the Convict Voice’, Tasmanian Historical Studies 6: 1, 1998, p. 83.

76 QSA, Series 15536 Information, Depositions and Associated Papers in Criminal Cases Heard in Sittings in Brisbane, Item ID 96093, November 1882, Regina v. Tina Brown.

77 PROV, VPRS 30/P0, Unit 571, 1881/10, Regina v. Florence Martin and Susan Pettit.

78 PROV, VPRS 30/P0, Unit 1023, 1895/262, Regina v. Josephine King and Catherine Turner.

79 Brisbane Courier, 13 Jan. 1892, p. 3; Truth (Brisbane), 21 Dec. 1902, p. 4; Truth (Brisbane), 15 March 1903, p. 3.

80 Wilson, 'Commodifed Craft', p. 148.

81 Fashion and Modernity, ed. Christopher Breward and Caroline Evans, Oxford, 2005; Susan Hiner, Accessories to Modernity: Fashion and the Feminine in NineteenthCentury France, Philadelphia, 2010; Wilson, Adorned in Dreams.

82 Sally Alexander, 'Becoming a Woman in London in the 1920s and '30s', in Becoming a Woman and Other Essays in 19th and 20th Century Feminist History, London, 1994; Kirsten McKenzie, 'Being Modern on a Slender Income: "Picture Show" and “Photoplayer” in Early 1920s Sydney', Journal of Women’s History 22: 4, 2010.

83 Timothy Burke, 'The Modern Girl and Commodity Culture', in The Modern Girl Around the World, p. 163; Glennie, 'Consumption', p. 165.

84 Breward and Evans, 'Introduction', Fashion and Modernity, p. 2.

85 On this debate among feminists: De Grazia, 'Introduction', The Sex of Things:

Gender and Consumption in Historical Perspective, ed. De Grazia with Ellen Furlough , Berkeley, 1996, p. 7.

86 Rita Felski, The Gender of Modernity, Cambridge, 1995, p. 63.

87 Peiss, Cheap Amusements, pp. 8-9 and chap. 3; Peiss, 'Girls Lean Back Everywhere', pp. 351-3.

88 The Invisible Flâneuse? Gender and Visual Culture in Nineteenth-Century Paris, ed. Aruna D’Souza and Tom McDonald, Manchester, 2006; Deborah L. Parsons, Streetwalking the Metropolis: Women, the City and Modernity, Oxford, 2000. 
89 We take the term 'material strategies' from Material Strategies: Dress and Gender in Historical Perspective, ed. Barbara Burman and Carol Turbin, Oxford, 2003. 90 Barbara Burman, 'Made At Home With Clever Fingers: Home Dressmaking in Edwardian England', in The Culture of Sewing: Gender, Consumption and Home Dressmaking, ed. Burman, Oxford and New York, 1999, p. 34.

91 Frances, 'Gender', p. 33.

92 Burman, ‘Made At Home’, pp. 35-6.

93 Judith Allen, 'The Making of a Prostitute Proletariat in Early Twentieth-century New South Wales', in So Much Hard Work.

94 See, for example, Jonathan Friedman, 'Introduction', and Orvar Löfgren, 'Consuming Interests', in Consumption and Identity, ed. Friedman.

95 E. P. Thompson, The Making of the English Working Class, London, 1963, p. 13. 


\begin{abstract}
:
The cant word 'flash' has been used in Australia and other parts of the English-speaking world since the late eighteenth century. When it was applied to women, it referred to sexual and criminal knowledge and an interest in flamboyant clothes. This continued to be the case in the years between 1870 and 1910, the period dealt with in this article. Using Australian examples, we explore the flash street style affected by disreputable women - whether prostitutes, brothel madams, thieves, badly-behaved ballet girls, or young women institutionalized under 'industrial schools' laws. We show that eclecticism was the hallmark of these women's 'flash' style. Their look involved clothes that were second-hand and freshly purchased, ready-made and hand-sewn, fashionable and unfashionable, relying on an array of so-called 'traditional' and 'modern' dress practices. In showing this, we question the preoccupation of most scholarship on women's consumption with the 'modern' and 'new'. Placing too much emphasis on modernity underplays the durability of older practices of consumption and gender in this period while overplaying the impact of modernizing developments on sensibilities and everyday life.
\end{abstract}

Keywords: Street style, flash culture, rough femininity, fashion, hair, tattooing, prostitutes, consumerism, modernity. 